Symbolon Volume XXII. no. 2 (41)

\title{
Iluzia necesară a (dez)informării
}

DOI : $10.46522 / \mathrm{S} .2021 .02 .06$

\section{Ion INDOLEAN PhD}

Babeș-Bolyai University, Faculty of Theatre and Television ion.indolean@ubbcluj.ro

\begin{abstract}
The Necessary Illusion of (Mis)Information
The launch of the miniseries "The Loudest Voice" (Tom McCarthy, Alex Metcalf) in the summer of 2019 draws the attention once again on the manipulative power of massmedia. The production presented by Showtime in 2019 and taken over by HBO stirred an important interest, due to the subject it presents, namely the way in which in the mid-90s the Republican Roger Ailes built and consolidated on the American media market the Fox News television channel, through a radical approach, very politically engaged and, as later proved, immoral and sexist, toxic. The miniseries was produced at the same time as Ailes was accused, in 2016, of sexual abuse and harassment by former employees of the station, and at the time of his death, a year later, in 2017.

These two controversial topics attract the interest of the current world establishment, which offered the Golden Globe to Russell Crowe for his role in "The Loudest Voice" and nominated Charlize Theron and Margot Robbie for the Oscars based on their performances in "Bombshell", a film that also appeared in 2019 and dealt with the same subject, but from the perspective of the female colleagues harassed by Ailes.

Linking the ideas expressed by Noam Chomsky in the '80s and '90s and the way "The Loudest Voice" treats the illusion that the press often builds, I aim to follow the way the process of media manipulation is refined in time and becomes the main tool of the current political competition. It is extremely interesting the way in which, in just a few generations, the content of a debate no longer matters, but the performative act itself.
\end{abstract}

Key words: Roger Ailes; "The Loudest Voice"; Fox News; Noam Chomsky; Manipulation.

Când cercetătorul Jacob L. Nelson a început, în 2014, un studiu care încerca să determine dacă în Statele Unite, conservatorii şi liberalii îşi iau ştirile exclusiv de la organizaţii aliniate ideologic sau dacă mai degrabă recurg la canale populare, neutre politic, a fost surprins să remarce că (aproape) nimeni nu i-a chestionat presupunerea că acest centrism - apolitic, obiectiv, fără o agendă ideologică - poate exista în mass-media. Mai mult, nimeni nu a sesizat o problemă în afirmaţia lui conform căreia trusturi-gigant pre- 
cum MSNBC (liberal) și Fox News (conservator) erau comparabile - două părți opuse ideologic, dar fidele aceluiași tip de partizanat politic (Nelson 2019)

Trecerea câtorva ani poate nuanţa însă poziţii. În perioada 2017-2021, SUA a avut un președinte care

[...] şi-a dus luptele alături de cei mai proeminenți comentatori ai Fox News, a recrutat foști angajați ai Fox pentru funcții de top din ramura executivă și a depins de Fox pentru a-și transmite mesajul către susținători; nu în ultimul rând, a căutat să fie validat de Fox pentru felul cum a condus ţara

Nelson 2019

Putem presupune că Donald Trump a continuat să ceară confirmare la televizor, aşa cum o făcuse şi cât timp a fost gazda reality show-ului produs de NBC, The Apprentice (Poniewozik 2020), care i-a oferit destulă faimă - imaginea de afacerist genial - încât să o monetizeze în cariera politică fulminantă: „Emisiunea i-a resuscitat temporar norocul în afaceri, prin crearea iluziei că se descurca minunat" (Poniewozik 2020)

Având în vedere aceste circumstanțe, ipoteza preliminară de la care trebuie să plecăm este că MSNBC, CNN, Fox şi alţi mari jucători de pe piaţa media nu mai pot fi consideraţi doar emiţ̧ătorii unor informaţii despre realitatea cotidiană, ci şi-au adăugat, cu sau fără voia lor, statutul de canale propagandistice.

Această realitate nu este totuşi nouă, ea nu aparţine doar ultimilor ani, dar putem spune că angajamentul ideologic al canalelor media a sporit considerabil şi că asta a dus la polarizarea suplimentară a populației de rând. David Brock şi Ari Rabin-Havt sunt de părere că o vină importantă pentru această escaladare a luptei ideologice purtată de televiziuni o are apariţia Fox News, în 1996, şi discută despre „efectul Fox” (Brock şi Rabin-Havt 2012). Posibil să fie adevărată această judecată, dar în acelaşi timp se poate nuanţa suplimentar: apariţia Fox News nu a creat fenomenul şi poate că nici nu l-a intensificat atât de mult - fiindcă era oricum deja consolidat în societatea americană - ci 1a scos la lumină.

Dând voce populaţiei republicane - sceptici, naţionalişti, conservatori, non-elitişti etc. - Fox a reuşit să scoată la lumină teme şi preocupări pe care celelalte canale media nu le abordau. Mai mult, a arătat că nu doar anumite subiecte sunt urmărite, vândute, interesante, ceea ce a scos la iveală faptul că şi televiziunile aşa-zis liberale au, de fapt, parti pris-uri și interese, că şi acestea aleg să prezinte un subiect doar din anumite perspective. Diferenţa între Fox şi concurenţă e dată nu de partizanatul ideologic, ci de nuanţele fine cu care fiecare tabără operează propria versiune a adevărului şi - probabil - de structura ierarhică şi felul cum trusturile adversare înțeleg să se auto-guverneze:

Așa cum explică Feldman, «În timp ce MSNBC este cu siguranță partizan, traficând indignarea şi opinia, reportajele sale - chiar şi în emisiunile difuzate în prime ti$m e$ - au o relație mult mai clară cu faptele decât reportajele de pe Fox». Profesorul Universității Princeton, Andy Guess, repetă acest punct de vedere: «Nu există nicio în- 
Ion Indolean

doială că prezentatorii Fox News sunt tot mai confortabili traficând teorii ale conspirației și făcând apeluri la nativism, ceea ce reprezintă o diferență majoră faţă de omologii lor liberali».

Nelson 2019

Voi dezvolta suplimentar aceste direcţii puţin mai târziu, pentru că în acest moment este necesar să stabilesc un cadru teoretic general al discuţiei, cadru propus de analistul şi politologul Noam Chomsky la finalul anilor '80, când publica două volume care clarifică rolul trusturilor de presă. Ideile lui erau revoluţionare în acel moment, fiindcă subliniau ce probabil simţeau majoritatea, dar nimeni nu îndrăznea să spună.

\section{Modelul propagandei}

Noam Chomsky deplânge schimbarea de rol pe care au înregistrat-o instituţiile de presă: porniseră cu scopul de a informa cetăţeanul de rând, de a face un serviciu public prin oferirea de date nefiltrate ideologic, şi ajunseseră - din motive diverse, supuse sistemului - să piardă din vedere beneficiul cetăţenesc pe care se presupunea că îl fac. În Manufacturing Consent, alături de co-autorul Edward S. Herman, Chomsky demască ideea că mass-media acţionează în continuare ca un mecanism de control al puterii politice; că scopul acesteia ar fi rămas acela de a informa publicul, de a-l servi, astfel încât individul să se poată angaja mai bine în a înţelege realitatea procesului politic. De fapt, mass-media ne fabrică, ne impune consimţământul. Ne spune ce are nevoie puterea să ne spună, pentru a ne putea alinia. Noi consumăm mass-media şi, asiguraţi, îndoctrinaţi, liniştiţi, ne conformăm. Democraţia este înscenată cu ajutorul mass-media, care funcţionează ca o maşinărie bine unsă a propagandei (Chomsky şi Herman 1988). Chomsky numeşte această întreprindere drept model al propagandei şi identifică cinci filtre care funcţionează împreună, interacţionează şi se consolidează reciproc:

(1) dimensiunea, proprietatea concentrată, bogăția proprietarului și orientarea spre profit a firmelor mass-media dominante; (2) publicitatea ca sursă primară de venit a massmedia; (3) dependența mass-media de informațiile furnizate de guvern, lumea de afaceri și „,experți”, toate finanțate și aprobate de aceste surse primare și agenți ai puterii; (4) „flak” ca mijloc de disciplinare a mass-media; și (5) „,anticomunism” ca religie națională și mecanism de control.

Chomsky şi Herman 1988, 2

Sugestia lui Chomsky este că materia primă a ştirilor trebuie să treacă prin filtre succesive, lăsând numai reziduul purificat să treacă. Premisele discursurilor şi interpretărilor sunt astfel fixate pentru a deservi elita şi pentru a marginaliza orice formă de disidenţă. Rezultă un mecanism care funcţionează atât de natural încât jurnaliştii integri şi oneşti ajung să se convingă că aleg şi interpretează ştirile în mod obiectiv şi pe baza 
unor valori profesionale, deontologice. Constrângerile sunt atât de puternic înrădăcinate în sistem încât alternativele devin de neimaginat (Chomsky şi Herman 1988, 2).

Pentru a explica suplimentar acest model al propagandei, merită să discutăm pe rând cele cinci filtre şi să identificăm cum conlucrează: proprietarii (1) trusturilor media sunt în cele mai multe cazuri mari corporaţii şi de multe ori fac parte din conglomerategigant. Ce urmăresc? Profitul financiar. Prin urmare, jurnalismul de investigaţie, jurnalismul critic, reprezintă un impediment pentru aceste companii, care nu doresc să fie analizate în detaliu. Publicitatea (2) trebuie să fie mereu pozitivă. Companiile media cheltuiesc mai mult decât sunt dispuşi să plătească cei care le consumă, astfel încât golul rămâne să fie umplut de sponsori, prin companii de publicitate, care plătesc pentru segmente de public. Nu este decât un pas ca cel care consumă produsul media să devină el însuşi produsul. Cei care conduc sistemul, liderii (3) ajung să poată autoriza narativa. Jurnalistul îşi pierde puterea de a verifica ce fac guvernele, corporaţiile, marile instituţii, fiindcă îşi pierd relaţiile cu acestea şi nu mai primesc informaţii. Pierd accesul la sursă, la poveşti. Dacă, totuşi, continuă să fie critici, cei mulţi rămaşi de cealaltă parte îi vor discredita (4); acuzatorii lor o pot face fiindcă au fost îndoctrinaţi şi cred în acţiunea lor sau fiindcă au fost forţaţi; indiferent de motiv, publicul începe să îşi piardă încrederea în cei marginalizaţi, cărora li se construieşte imaginea unor nebuni. Când aceşti rebeli ai sistemului nu sunt de ajuns pentru a influența opinia publică, se creează inamici (5): duşmani comuni, cu chip de terorist, comunist, imigrant etc. În funcţie de moment şi de context, acesta poartă alt nume şi provine din alt context cultural.

Chomsky îşi dezvoltă suplimentar ideile publicate în 1988, un an mai târziu: 'Necessary Illusions' nuanțează felul cum statele occidentale, democratice, folosesc dubla măsură în politicile interne şi mai ales în cele externe: „este o așteptare firească, pe ipoteze necontroversate, că mass-media și alte instituții ideologice vor reflecta în general perspectivele și interesele puterii" (Chomsky 1989, 21). Teoreticianul american oferă exemple din acel moment, al finalului de Război Rece:

[...] nu este nevoie de nicio dovadă pentru a condamna Uniunea Sovietică pentru agresiune în Afganistan și sprijin pentru represiune în Polonia; este o chestiune cu totul diferită atunci când se vorbeşte despre agresiunea SUA în Indochina sau eforturile acesteia de a preveni o soluționare politică a conflictului arabo-israelian de-a lungul mai multor ani, documentată cu promptitudine, dar indezirabilă și, prin urmare, un non-fapt.

Chomsky 1989, 20-21

Putem găsi comportamente similare şi în trecutul apropiat: scandalul economic dintre SUA şi China (Economy et al. 2020), embargoul asupra Venezuelei din 2019 ordonat de preşedintele Trump (Kirschner 2021), schimbarea de atitudine dintre Uniunea Europeană şi Marea Britanie în urma Brexit etc (Albrecht et al. 2021). Țintele principale ale acestor mesaje sunt, surprinzător oarecum, conducătorii unor comunităţi, cei care se consideră intelectuali şi lideri de opinie. De ce? Fiindcă ei pot mobiliza publicul. Pot 
Ion Indolean

propune dezbateri publice, pot naşte chiar şi controverse - întărind astfel ideea de libertate a expresiei - atâta timp cât se află înăuntrul unor limite impuse aprioric (Chomsky 1989, 70).

Când aceste limite sunt depăşite, reprezentanţii mass-media intervin prompt şi discreditează nu numai ideile propuse de rebeli, cât - mai important - persoanele lor, găsindu-le greşeli ale trecutului, opinii dezagreabile, inconsecvenţe în argumentaţie. Orice mic detaliu care îi poate destabiliza şi le poate compromite credibilitatea, va fi speculat.

Cazul Fox News revine astfel în discuţie, fiindcă reprezintă exemplul perfect al felului în care establishment se scindează la un moment dat şi începe să ducă o luptă internă, de gherilă, unde fiecare parte - reprezentantă a unui segment al politicienilor şi afaceriştilor de prim rang - luptă pentru a acapara toată puterea, toată sfera de influenţă asupra politicilor şi (aici fiind de fapt cheia) opiniei publice.

\section{The Loudest Voice in the Room}

Trustul media Showtime realizează în 2019 o miniserie de şapte episoade, numită The Loudest Voice, prin care încearcă să înţeleagă felul în care Fox News ajunge relativ rapid de la un post nou înfiinţat în topul rating-urilor americane. Adoptând o abordare aparent neutră, obiectivă, echilibrată, seria creată de Tom McCarthy şi Alex Metcalf după cartea lui Gabriel Sherman (The Loudest Voice in the Room: How the Brilliant, Bombastic Roger Ailes Built Fox News-and Divided a Country) - reţine momentele esenţiale pentru succesul postului creat de Roger Ailes - cu sprijinul financiar al mogulului australiano-american Rupert Murdoch. Fără să intre în detalii de nuanţă, seria are meritul de a reflecta modul de operare al lui Ailes, caracterizat prin control şi teroare. Totodată, producţia reţine şi personalitatea celui care a făcut parte din echipa câştigătoare a lui Richard Nixon, dar aminteşte doar tangenţial perioada tinereţii lui Ailes, când şia format convingerile conservatoare şi modul radical de operare.

Seria începe cu aspectele cele mai recente în legătură cu Roger Ailes: moartea lui din 2017, acuzaţiile de hărţuire sexuală începute în 2016, urmate de un discurs propriu (interpretat de un Russell Crowe schimbat fizic total) prin care anticipează criticile inamicilor săi: ,de dreapta, paranoic, grăsan” (The Loudest Voice 2019). Apoi, revenind în trecut, povestea porneşte în 1995, când Ailes începe munca la construirea Fox News: „,sunt conservator; îmi place să mănânc; şi cred în puterea televiziunii; trebuie să le oferi oamenilor ce îşi doresc, chiar dacă ei nici nu ştiu că asta îşi doresc" (The Loudest Voice 2019). Acest discurs e relevant pentru atitudinea seriei faţă de Ailes: fascinaţie combinată cu consternare, contestatare. Operarea cu două perspective atât de diferite, contradictorii, este menită să atragă fani din ambele tabere.

Ailes află că este demis de la NBC, aşa că îşi lasă o portiţă contractuală prin care să poată merge la alt trust de presă, dacă acesta încă nu există. Rupert Murdoch îl contractează pentru a constitui un canal TV care să speculeze segmentul pieţei publicului con- 
servator, republican. Primele trei episoade explică modul de operare al lui Ailes, felul cum și-a ales angajaţii, ideile politice, strategia media, mentalitatea lui conform căruia totul în viaţă reprezintă o luptă cu tabăra inamică. Primul episod se termină cu un discurs însufleţitor, care adună laolaltă toate aceste aspecte:

De 50 de ani, politica de stânga din ţara aceasta încearcă să controleze programele de ştiri. Le-au băgat pe gât americanilor cu agenda lor guvernamentală. Şi ştiţi la ce a dus asta? La apariţia unei oportunităţi. Dacă vrem să învingem CNN, MSNBC, CNBC, trebuie să facem un legământ de loialitate, de loialitate unii faţă de alţii şi faţă de misiunea noastră. Iar misiunea este să-l convingem pe americanul uitat că vocea lui se poate face auzită şi o va face, în democraţia noastră. Le vom oferi o perspectivă reală asupra lumii şi perspectiva pe care îşi doresc să o vadă. Şi, când vom face asta, ştiţi ce se va întâmpla? Vom recâştiga adevărata America. Contestăm agenda din prezent şi devenim cea mai zgomotoasă voce! Şi restabilim echilibrul şi obiectivitatea în ţara asta!

The Loudest Voice 2019

Cultura intimidării şi a conflictului, a fricii, sunt ceea ce vinde Ailes. Abordarea lui estompează distincţia între politică şi ştiri, între opinie şi jurnalism. O zi de transmisiune Fox include ,furia, bombasticul, şirul paranoic virulent, apelul nesfârşit la resentimentul celor albi" (Dickinson 2011). Gabriel Sherman, autorul cărţii pe baza căreia s-a realizat The Loudest Voice, descrie, în 2014, chiar după publicare, felul totalitar în care Fox News este condus. El subliniază că - după părerea lui - Fox nu este o organizaţie de ştiri, ci o organizaţie politică unde se întâmplă să lucreze câţiva jurnalişti. Mai mult decât atât, reprezintă un cult al personalităţii pentru un singur om, Roger Ailes; întreaga organizaţie există pentru a-1 mulţumi pe şef (Sherman 2014). Sherman subliniază că cercul restrâns al lui Ailes ar fi terifiat de el, că nu a văzut nicăieri altundeva o asemenea exercitare a puterii şi că nivelul de paranoia ajunsese la cotele cele mai ridicate. Putem urmări şi în serie felul cum, odată cu atentatele din 2001, Ailes şi apropiaţii lui se află într-o permanentă stare de alertă, într-un război continuu. Sherman e de părere că motivul succesului Fox News constă în această cultură absolutistă şi oferă un exemplu pe care îl găseşte relevant: angajaţii se gândesc să producă știri care să-i facă pe plac lui Roger Ailes și, de fapt, uneori Fox News are probleme, deoarece producătorii vor depăşi măsura pentru că sunt foarte dornici să îi facă şefului pe plac (Sherman 2014).

Între evenimentele cuprinse în primul şi al doilea episod, există o întâmplare extrem de importantă lăsată deoparte de creatorii seriei: alegerile prezidenţiale din 2000 , când Fox News a punctat decisiv în victoria lui George W. Bush. Operaţiunea este relevantă pentru această nouă formă de campanie politică orchestrată cu ajutorul unui trust de presă. Pe scurt, lucrurile au stat în felul următor: cu toate că înfruntarea nu era nici pe departe tranşată, Fox News 1-a declarat prematur pe Bush drept câştigător, ceea ce i-a atras mai multe procese în instanță. Ailes, decis să nu lase nimic la voia întâmplării, 1-a numit în acea zi la cârma pupitrului de decizie pe John Prescott Ellis, verişor primar cu Bush. În orice alt trust, un asemenea conflict de interese l-ar fi descalificat pe Ellis. Nu şi aici, unde loialitatea faţă de viitorul preşedinte a devenit un bun. În acea noapte, Fox 
1-a numit pe Bush câştigător, cu toate că în Florida diferenţa de voturi era încă prea mică pentru a şti cu exactitate acest lucru (Sherman 2014). Prezentatorul, Brit Hume, a dat verdictul la ora 2:16 a.m., iar toate celelalte canale au preluat informaţia aproape instant, ca pe urmă să o retracteze ruşinate, cu mai puţin de două ore mai târziu (Kurtz 2000). Esenţială aici a fost capacitatea de a controla povestea în aşa fel încât cetăţenii să creadă informaţia.

Pentru Ailes, detaliile nu contează atunci când ele contravin cu mesajul general. El sublinia în cartea sa că publicul ţine minte doar concepte şi expresii emoţionale, comunicate prin ochi, chip, voce şi corp (Ailes şi Kraushar 2012). Liderii nu sunt aleşi pe baza detaliilor programelor pe care le propun, ci mai degrabă pe anumite teme (Dickinson 2011). O asemenea întâmplare se petrece în cazul lui Ronald Reagan, în timpul campaniei din 1984, când viitorul preşedinte reales prezenta semne incipiente de Alzheimer. Ailes 1-a sfătuit să transforme bătrâneţea într-un atuu, motiv pentru care Reagan a jucat generozitatea când a spus că nu va exploata, pentru motive politice, tinereţea şi lipsa de experienţă a adversarului său (Dickinson 2011).

Este interesant de observat cum The Loudest Voice omite astfel de detalii care i-ar conferi lui Ailes - pe lângă imaginea de tiran - aura unui geniu strategic. Episodul al doilea al seriei se concentrează asupra felului cum atentatele teroriste de la 11 septembrie 2001 influenţează agenda Fox News. Ailes şi-a consolidat crezul de a fi angajat politic în mass-media şi a încercat să construiască - în jurul acestei tragedii - o şi mai intensă coeziune la nivelul echipei sale de reporteri. El a speculat gravitatea atentatului pentru a consolida agenda personală, dar şi pentru a aduce postul în prim-plan. Fox News devine astfel cel mai mare jucător din piaţă, pentru că are o abordare senzaţionalistă. Ailes s-a folosit de tiparul duşmanului comun pentru a-şi aduce toţi colaboratori în aceeaşi stare şi de aceeaşi parte. Prin felul cum este realizată, seria dă falsa impresie că Fox îşi ridică iniţial rating-ul prin mediatizarea excesivă a atentatelor. Acest lucru este greu de crezut, dat fiind că ele se petrec la cinci ani de la crearea postului. Scenariul atribuie aici o culpă morală lui Ailes, care decide, în ciuda tuturor criteriilor deontologice, să difuzeze imagini cu oameni care sar din blocurile gemene. Argumentul şefului este că toată lumea trebuie să vadă ce „ne-au făcut animalele alea”. Este momentul în care Ailes găseşte acel scop suprem pentru Fox News, sugerează scenariul:

Nenorociţii aceia habar nu au ce au început. Vor fi distruşi, striviţi, le vom pune bordeiele în pământ. La Fox News... avem o misiune importantă. [...] Deja nu mai e vorba de politică. Suntem în război.

The Loudest Voice 2019

Este adevărat că nivelul de paranoia - aşa cum sunt de părere mai mulţi reporteri creşte odată cu evenimentele de la 11 septembrie, dar modificarea din comportamentul lui Ailes - aşa cum o sugerează seria - pare accentuată în mod deplasat. Această atitudine, totuşi uşor părtinitoare se poate vedea şi din selecţia momentelor pe care The Loudest Voice le acoperă în continuare. Nu este un lucru nemaiîntâlnit în producţiile comer- 
ciale - care caută senzaţionalismul şi de multe ori mizează pe cele mai cunoscute aspecte din existenţa celor prezentați pe ecran, fiindcă astfel cât mai mulţi spectatori se pot identifica cu acestea, prin faptul că şi le amintesc - dar merită menţionat pentru a păstra un discurs echilibrat. Seria editorializează pe marginea activităţii lui Ailes, adică selectează cele mai mari derapaje ale sale şi le exagerează în aşa fel încât orice spectator să îi înțeleagă personalitatea, abordarea.

Episodul al treilea sare aşadar câţ̧iva ani şi ajunge în 2008, în timpul campaniei electorale în urma căreia Barack Obama devine primul preşedinte de culoare al Statelor Unite. Ailes cel interpretat de Russell Crowe îşi arată din start nemulţumirea vizavi de acest candidat: „Democraţii au nominalizat un african socialist care vrea să redistribuie bogăţia ţării” (The Loudest Voice 2019). Miza lui este să îi facă pe americani să-l creadă pe Obama musulman, terorist şi străin. Îl aseamănă cu Hitler şi Stalin, între care nu face diferență, pentru a sublinia o generalizare care poate funcţiona în mintea publicului; el aduce laolaltă mai multe clişee - care fiecare singur nu ar fi de ajuns, dar împreună pot forma un scenariu solid - astfel încât alăturarea şi repetarea lor să poată fi destul de convingătoare. La Fox News, insistă ca lui Obama să i se spună cu cel de-al doilea prenume, Hussein, pentru a da impresia unui terorist. Este interesant că la doar câţiva ani distanță, Traian Băsescu se referea la adversarul său, Victor Ponta, cu apelativul de Viorel (al doilea său prenume) (HotNews 2014), cu acelaşi scop defăimător. Cu conotaţii diferite, dar în ambele cazuri negative, Ailes, respectiv Băsescu folosesc prenumele mai puţin cunoscut pentru a construi o imagine negativă. În cazul lui Obama, putem vorbi despre ideea de musulman; în cazul lui Ponta despre ideea țăran, needucat, simplu, nevrednic să ocupe o poziţie importantă de conducere.Această accentuare pe care o face seria este dublată de finalul episodului, când Ailes însuflețeşte prin discurs o masă de oameni, dominată de chipuri needucate, uşor manipulabile etc.

Următorul episod subliniază mania pe care Ailes o creează la nivel societal. Fox News sugerează că victoria lui Obama ar atrage o guvernare socialistă, nespecific americană, prin care liderii ar lua de la bogaţi şi ar da la săraci. Este tipul de simplificare cu care lucrează propaganda, care trebuie să fie directă, reductivă, generalizatoare şi de impact.

Ultimele trei episoade urmăresc momente mai recente.

De pildă, operaţiunea de discreditare a scriitorului Gabriel Sherman este importantă atât pentru contextul realizării producţiei, cât şi pentru că prezintă încă o dată modul de operare al lui Ailes, dorinţa lui de a controla mereu povestea, atât în privinţă politică mai largă, cât mai ales la nivel personal. Este interesant faptul că în anul apariţiei cărţii lui Sherman, jurnalistul Jill Lepore scrie pentru 'The New Yorker' un articol despre Roger Ailes în care îl compară cu William Randolph Hearst - din viaţa căruia regizorul Orson Welles s-a inspirat pentru filmul său de referinţă, Citizen Kane (1941). În perioada interbelică, Hearst domina presa americană prin intermediul trustului Hearst Communications. Lepore remarcă două asemănări izbitoare între acţiunile celor doi moguli: fiecare condusese trusturi media bazate pe conflict şi intrigă, care şocau opinia publică 
la vremea lor; fiecare aflase că un scriitor independent e pe cale să publice o biografie nu tocmai măgulitoare despre persoana lor şi apelase la câte un lacheu pentru a scoate o variantă autorizată a activităţii lor (Lepore, 2014).

Alt moment pe care seria îl pune pe ecran reprezintă începerea tratativelor de a-1 transforma pe Donald Trump într-un prezindenţiabil cu şanse reale de câş̧ig. De ce e Donald greu de contracarat într-un joc politic clasic? Pentru că nu joacă după reguli: nu poate fi atacat pentru tipul de greşeli care ar funcţiona în cazul altora (scandaluri sexuale, jigniri, inconsecvenţe în declaraţii etc.); el şi le asumă, le atacă sau le bagatelizează gravitatea, iar aşa îşi transformă urmăritorii în adepţi; ei devin atât de radicalizaţi încât nu mai au discernământul de a analiza în mod raţional activitatea idolului lor. Trump nu este un politician, ci un om venit din showbiz.

În acest moment al seriei intervine fugitiv şi personajul lui Roger Stone, un consultant politic controversat şi extrem de mediatizat. The Loudest Voice nu explică felul cum Stone contribuie la campania câş̧tigătoare a lui Trump, cu toate că i-ar putea folosi personalitatea îndoielnică pentru a-l ataca suplimentar pe Ailes. De ce îndoielnică? Pentru că Stone se ghidează după reguli precum aceasta: „Este mai bine să fii infam decât să nu fii niciodată celebru” sau „Mă delectez cu ura ta, pentru că dacă nu aş fi eficient nu m-ai urî." (Gilbert 2017). Despre importanţa lui Stone discută, printre altele, filmul Get Me Roger Stone (2017), realizat în timpul campaniei lui Trump şi prezentat chiar după terminarea acesteia. Stone reiterează şi nuanţează ideea că alegătorii nu fac distincţie între divertisment şi politică, motiv pentru care fostul preşedinte american a obţinut această poziţie:

The Apprentice 1-a făcut un interpret de televiziune elegant; gândiți-vă la modul cum arăta în spectacol: scaun cu spate înalt, perfect luminat, păr şi machiaj grozav, decisiv, luând decizii, conducând spectacolul; arăta prezidențial. Credeți că alegătorii, non-sofisticaţii, fac diferenţa între divertisment şi politică? Politica este spectacol pentru oamenii urâți.

Renata s.a.

Stone îşi completează filosofia prin a puncta faptul că:

[...] sarcina unui strateg politic este să exploateze reclame negative, dar memorabile, în scopul câștigării voturilor. Trucul este să te poți angaja în campanii negative fără să fii perceput pe scară largă ca desfășurând o campanie negativă.

Stone 2018

Aceeaşi filosofie o aplică şi Ailes, atunci când angajează Fox News în diverse scandaluri mediatice. El adoptă mereu o strategie ofensivă, în care nu îşi acceptă greşelile, ci supralicitează în speranţa ca adversarii lui să cedeze. Seria prezintă felul cum reacţionează atunci când opinia publică află despre harţuirea sexuală asupra angajatelor şi 
campania \#MeToo. ${ }^{1}$ De asemenea, este interesată de mania tot mai mare legată de conspiraţiile din jurul lui şi de radicalizarea suplimentară a celor puţin rămaşi în tabără lui.

Cinismul prezentat aici e şocant. Aceste episoade devin şi mai angajate în a-1 discredita pe Ailes; par pe undeva mai lipsite de echilibrul impus în prima parte a seriei, când personalitatea lui machiavelică naşte o oarecare fascinaţie - chiar dacă mai degrabă negativă. Aici, Ailes începe să devină un om meschin şi mărunt, care luptă să păstreze aparenţa publică: el începe să piardă controlul, îşi îndepărtează cei mai loiali colaboratori şi se vede incapabil să mai continue minciunile. Lucrurile ies la iveală. Seria face o delimitare între eşecul personal din ultimii ani ai lui Ailes (când începe să piardă influenţă în trustul media şi credibilitate în ochii opiniei publice), respectiv succesul ideologic pe care îl asigură metoda rafinată de acesta.

Testamentul pe care îl lasă umanităţii, ultima lui moştenire, este Donald Trump. Seria sugerează că Ailes îl consideră candidatul ideal pentru a modifica paradigma politică şi pentru a readuce puterea de partea Partidului Republican. Aici seria începe să lucreze mai degrabă în alb şi negru, dar reuşeşte să sublinieze importanţa pe care Fox News a avut-o în alegerea lui Trump şi prezintă foarte sumar şi generalizat abordarea câş̧tigătoare propusă de Ailes: „Aş̧a cum facem la Fox: ne concentrămpe o idee sau două pe care le repetăm la nesfârşit. La un moment dat, în mintea acelor oameni, acele idei devin adevărul care le este familiar" (The Loudest Voice 2019). Pe fundalul acestei lecţii, curg imagini de arhivă cu manifestaţiile lui Trump în care repetă ideea de a construi acel zid la graniţa cu Mexicul - ,build that wall, build that wall...”.

The Loudest Voice sugerează că aceasta ar fi povestea unui om învins: Ailes rămâne să se uite singur, pe canapeaua de acasă, la discursul lui Trump, pentru că soţia lui nu reuşeşte să îl mai consoleze - înţelegând şi acceptând eşecul de a fi pierdut contactul cu realitatea, ceea ce el pare că nu face - şi izbucneşte în plâns, ieşind din cadru. Să fie chiar aşa? Seria produsă de Showtime prezintă condensat maniile lui Ailes. Fără să căutăm şi în alte părţi, dacă ne uităm doar la această ecranizare, descoperim un psihopat, egocentrist, radical, închis în propria enclavă ideologică. Comparând această imagine cu apariţiile publice - interviuri, prelegeri, conferinţe - observăm o personalitate mult mai rafinată, un individ care se ştie face şi plăcut: direct, într-adevăr tranşant, dar îndeajuns de echilibrat încât ideile lui să penetreze mintea celor din jur. Ailes are calităţile unui lider: dur, categoric, interesat de aceleaşi teme (proprii conservatorismului), dar şi un bun ascultător, un gânditor, unul care înțelege importanța introspecţiei şi ştie cum să se comporte în diferite conjuncturi (YouTube 2010, 2015, 2016).

Consensul criticii americane de film privind The Loudest Voice ne-ar face să credem că seria nu a fost îndeajuns de dură cu Ailes, că a ratat o şansă istorică de construi „o

${ }^{1}$ \#MeToo reprezintă o campanie de conştientizare a abuzurilor asupra femeilor. A devenit virală în 2017, întâi prin intermediul platformelor de socializare Facebook şi Twitter, şi le-a oferit curajul unui număr foarte mare de persoane din întreaga lume de a vorbi deschis despre abuzurile suferite în trecut. 
acuzaţie puternică faţă de una dintre cele mai infame figuri ale presei" (Rotten Tomatoes s.a.). Abordarea seriei, aflată undeva la mijlocul spectrului - chiar dacă uşor (a)trasă către a-1 critica pe Ailes - confirmă încă o dată modelul propagandei propus de Noam Chomsky, fiindcă producția prezintă un subiect controversat, naşte o dezbatere, le oferă simpatizanţilor ambelor tabere ceva de care să se poată agăţa. În funcţie de poziţia adoptată, fiecare spectator poate să îşi consolideze propria credinţă: că tot ce a făcut Ailes a fost oribil sau, dimpotrivă, a demonstrat genialitate. Ailes ca lider pragmatic şi nemilos sau Ailes ca obsedat sexual şi lipsit de umanitate? Depinde ce vrem să alegem. Prin această plasare la centru, seria devine universal vandabilă pentru publicitatea plătită în ambele tabere ideologice, fiindcă reuşeşte să nu supere decisiv pe nimeni. Este tocmai acel tip de abordare care nu iese din limitele (auto)impuse.

Dincolo de imaginea pe care seria o construieşte trustului Fox News - cu agenda proprie şi cu limitările de timp specifice unei producţii audio-vizuale - este interesant să ne întrebăm de ce trustul TV are un succes atât de mare şi în ce segment al societăţii americane reuşeşte să penetreze cel mai bine.

\section{Cine și cum consumă Fox News?}

Pentru a înţelege mai bine impactul puternic şi publicul ţintă al canalului, este important de reluat faptul că Fox News a fost confecţionat după chipul şi asemănarea lui Roger Ailes. Cariera lui Ailes în televiziune a început în 1961, în Cleveland şi Philadephia, unde în câţiva ani a trecut de la asistent la producător al emisiunii locale 'The Mike Douglas Show', pe care a transformat-o într-un program cu impact naţional - cele două Premii Emmy $(1967,1968)$ demonstrează această transformare.

După startul fulminant, urmează o carieră de consultant politic şi participă în echipele câştigătoare pentru trei preşedinţi americani: Richard Nixon (1968), Ronald Reagan (1984), George H. W. Bush (1988). Revine în televiziune în 1993, la CNBC, pentru care produce emisiuni de succes, dar este înlăturat de aici înainte să acapareze prea multă putere şi influenţă. În ciuda eşecului său, aici probează prima oară ideea - fără să o ducă la desăvârşire - de a construi un trust media ,corect şi echilibrat”, sloganul pe care îl (va) impune la Fox.

Cariera lui Roger Ailes pare provenită dintr-un scenariu de film: confecţionată minuţios, cărămidă cu cărămidă, până în momentul când se simte pregătit - şi are sprijinul material necesar - să construiască cel mai de succes post TV american. Experienţele prin care trece par să îl pregătească pentru acest moment. Mogulul media Rupert Murdoch îi oferă mână liberă şi îi permite să îşi alcătuiască propria echipă şi politică redacţională, atâta timp cât profitul este considerabil. Impunerea pe piaţă vine cu un mare cost financiar iniţial: Murdoch plăteşte companiile de cablu câte 20 de dolari pentru fiecare abonat, înmulţit cu 25 de milioane, ca acestea să includă Fox News în grila lor de canale. Injecţia de capital - jumătate de miliard de dolari - reprezintă un risc despre care Murdoch afirmă: „Acesta este capitalismul şi unul din lucrurile care fac această 
țară să fie mare" (Dickinson 2011). Dar este un risc calculat. Ailes şi Murdoch au înțeles lipsa unei voci media puternice care să reprezinte ideologia naţionalistconservatoare, lipsa de orizont a generaţiei baby-boomer, care trăise bine în prima parte a vieţii, iar acum îşi vedea drepturile şi privilegiile pierdute unul câte unul. Dorinţa lor, cel puţin cea afirmată la televizor, era de a face America măreaţă din nou ('Make America Great Again'), sintagmă preluată de la Ronald Reagan, care o folosise în 1980 (Taibbi 2015) - când economia ţării se afla în stagflaţie (Hill 2015) - şi însuşită ulterior de Donald Trump.

Economic, cultural şi social, acesta este contextul intrării Fox News în piaţă, la mijlocul anilor '90. În anii 2000, când postul devine lider în privinţa rating-urilor şi când îşi consolidează audienţa, Fox ştie cui se adresează. Conform unor statistici prezentate de jurnalistul Tim Dickinson, în 2011 - deci la finalul deceniului în care Fox reuşise să influenţeze succesul lui George W. Bush - urmăritorii canalului ar fi aparţinut în mare parte generaţiei baby boomer, ar fi fost aproape exclusiv de rasă albă (98\%), ar fi fost orientată pro-business $(86 \%)$, creștin-conservatoare $(78 \%)$, fără diplomă de colegiu (66\%), cu vârsta de peste 50 de ani (65\%), în favoarea portului de armă (73\%), împotriva drepturilor comunităţii negre (78\%), de părere că guvernul face prea mult $(84 \%)$ (Dickinson 2011). Dintre urmăritorii avizi ai postului, două treimi erau convinşi că programul 'Obamacare' ar duce la o preluare guvernamentală, ar oferi îngrijiri medicale imigranților ilegali, ar plăti pentru avorturi şi ar lăsa guvernul să decidă când să o scoată pe bunica de la aparate (Dickinson 2011).

Strategia postului pare să fie de a face apel la instincte în detrimentul gândirii raţionale. Intenţia nu este de a informa, ci de a diviza, ca strategie de marketing folosind ideea noi versus ei. Fox News pare să spună că liberalii sunt răi, pentru că vor să ofere mai multe drepturi minorităţilor şi să restrângă din drepturile majorităţii. Rezultatul acestei campanii concertate de dezinformare poate fi îngrijorător: oamenii nu cunosc aproape nimic din realităţi, rămân prost informaţi sau chiar dezinformaţi, devenind în timp ignoranţi în faţa dezbaterilor şi a altor puncte de vedere. Dickinson subliniază că Ailes - la fel ca mentorul său politic, Richard Nixon - trafichează emoţia victimizării (Dickinson 2011).

Strategia ideologică a postului a dat roade acolo unde contează cel mai mult: alegerile prezidenţiale din 2000, care spuneam că au fost câştigate de George W. Bush. Republicanul a învins în ciuda faptului că a obţinut mai puţine voturi din partea cetățenilor. Fără să intru în detalii privind procesul de votare din Statele Unite, este important de ştiut că - simplificând foarte mult - fiecare stat al țării e câsştigat unitar de candidatul cu mai multe voturi, iar aceasta înseamnă că voturile strânse în acel stat de adversarul lui devin nule.

Stefano DellaVigna şi Ethan Kaplan explică în mod ştiinţific faptul că intrarea Fox News pe piaţa media a reuşit să aducă Partidului Republican două sute de mii de voturi în plus (DellaVigna şi Kaplan 2007). Cu toate că nu pare mult faţă de cei o sută de milioane de votanţi din 2000, este posibil ca aceste voturi, obţinute strategic în anumite sta- 
te, să fi înclinat decisiv balanţa în favoarea lui Bush. Această victorie a fost repetată în 2004; se spune că Murdoch şi Ailes au sărbătorit în biroul lor până la trei dimineaţa (Dickinson 2011). Iată, legătura apropiată dintre Fox şi republicani a fost benefică nu numai pentru rating, ci şi economic şi politic. Privind şi succesul din 2017 al lui Donald Trump, este greu de crezut teza seriei The Loudest Voice, conform căreia Ailes moare ca om învins de sistem. Se spune că ar fi zis la un moment dat următoarele: „Nu sunt jurnalist, sunt un entertainer şi câştig". ${ }^{2}$

Se pare că imediat după acuzaţiile de hărţuire sexuală din 2016 şi moartea lui în 2017, la Fox News lucrurile rămăseseră la fel. Cel puţin, aşa argumenta CNN, canal concurent al Fox (Byers 2019). Câţiva ani mai târziu, tot CNN sugera că lucrurile în continuare nu s-au schimbat prea mult, dar sublinia că Donald Trump credea contrariul (conform postărilor sale de pe Twitter din 2020) şi se întreba retoric unde este Roger Ailes, unde sunt vremurile în care trustul îl susţinea necondiţionat (Stelter 2020). Vedem, iată, o posibilă diferenţă de nuanţă între ultimele două campanii pentru preşedinţia Statelor Unite $(2017,2021)$ în abordarea Fox News. Probabil, trustul a devenit mai puţin vehement, mai puţin dispus să lupte necondiţionat pentru cauza republicană, dar rămâne în continuare cel mai important jucător media aflat în favoarea conservatorismului american. Lupta pe care celelalte trusturi o duc cu Fox News rămâne de actualitate.

Lupta ideologică, prin canalele media, se poartă în toată lumea, ea nefiind proprie doar Statelor Unite. La fel se întâmplă în România, unde trustul RCS RDS, prin canalul Digi24 (HotNews 2012) - unde, în 2012, se promova ideea că abonaţii pot cere companiilor să le scoată Antena 3 din grila de programe şi despre care se spunea că ar fi o „contrapondere necesară la Antena 3 și România TV pe piața televiziunilor de știri, oferind o alternativă rezonabilă la posturile de propagandă pură” (Tăpălagă 2019) - şi CNN promovează o idee similară în legătură cu Fox News, sublinia Tucker Carlson, unul dintre cei mai vizibili prezentatori ai postului lui Murdoch (Carlson 2021).

Probabil uşoara modificare de atitudine în privinţa Fox News ţine şi de faptul că Trump părea că va pierde alegerile din 2020-2021 (ceea ce s-a adeverit), iar Murdoch a procedat la fel ca în 2008, când a insistat ca Ailes să îşi tempereze politica denigratoare la adresa lui Obama, fiindcă simţea că democratul va câştiga şi nu dorea un duşman total la Casa Albă. Aceste două evenimente - structurate asemănător şi caracterizate printr-o temperare a furiei Fox faţă de tabăra democrată - dovedesc faptul că Murdoch se orientează doar parţial ideologic, fiind mai preocupat de câştigul financiar. Faţă de Ailes, Murdoch pare mai maleabil în privinţa gradului de angajare politică a trustului său media.

Parcursul, ascensiunea şi felul cum Fox News schimbă povestea în Statele Unite, propunând totodată un mod şi mai implicat politic de a face jurnalism, sunt relevante în raport cu ideile prezentate de Noam Chomsky, fiindcă putem înţelege în mod concret

${ }^{2} \mathrm{Nu}$ am găsit o mărturie înregistrată, dar mulţi comentatori au sugerat, într-un fel sau altul, acest eveniment. 
cum se translatează teoria în practică. În acest sens, putem depista iluzia pe care de multe ori o construieşte presa, cum lupta ideologică se înteţeşte de la o generaţie la alta şi mijloacele tot mai diverse prin care publicul poate fi implicat politic. Totodată, înţelegem felul cum procedeul manipulării mass-media este rafinat în timp, devenind unealta principală a luptei politice din prezent. Este extrem de interesant felul cum, în doar câteva generaţii, ajunge să nu mai conteze conţinutul unei dezbateri, ci actul performativ în sine, unde atinsă nu mai trebuie să fie inteligenţa, ci emoţia cetăţeanului

\section{REFERINȚE}

AILES, Roger şi KRAUSHAR, Jon, 2012. You Are The Message, New York: Crown Business.

BROCK, David şi RABIN-HAVT, Ari, 2012. The Fox Effect: How Roger Ailes Turned a Network into a Propaganda Machine, New York: Anchor Books.

CHOMSKY, Noam, 1989. Necessary Illusions. Thought Control in Democratic Societies, London: Pluto Press.

CHOMSKY, Noam şi HERMAN S. Edward, 1988. Manufacturing Consent: The Political Economy of the Mass Media. New York: Pantheon Books.

DELLAVIGNA, Stefano şi KAPLAN, Ethan. The Fox News Effect: Media Bias and Voting. The Quarterly Journal of Economics, Volume 122, Issue 3, August 2007, p. 1187-1234.

SHERMAN, Gabriel, 2014. The Loudest Voice in the Room: How the Brilliant, Bombastic Roger Ailes Built Fox News-and Divided a Country, New York: Random House.

Articole de presă:

ALBRECHT, Michael, JUNCK, Ryan, MCGOLDRICK, Vanessa, ROBERTSON, Elizabeth, şi SÈVE, Margot, 2021. Impact of Brexit on UK and EU Sanctions Frameworks [online]. JD Supra. [Accesat 5 mai 2021]. Disponibil la: https://www.jdsupra.com/legalnews/impact-of-brexit-on-uk-and-eu-sanctions7672025/

BYERS, Dylan, 2017. One year after Roger Ailes' departure, Fox News thrives as an unabashed Trump booster [online]. CNN Business. [Accesat 5 mai 2021]. Disponibil la: https://money.cnn.com/2017/07/21/media/fox-news-roger-ailesdonald-trump/index.html

CARLSON, Tucker, 2021. From Twitter to CNN, the left is coming for your speech [online]. Fox News. [Accesat 5 mai 2021]. Disponibil la: https://www.foxnews.com/opinion/tucker-carlson-on-twitter-and-cnn

C.I., 2012. Antenele - scoase oficial din grila RCSRDS pe platforma de satelit Digi [online]. HotNews. [Accesat 5 mai 2021]. Disponibil la: https://m.hotnews.ro/stire/12340301 
Ion Indolean

C.I., 2012. UPDATE Antena 1, Antena 3 si Euforia ies din grila RCSRDS pe platforma de satelit Digi care are peste 1,1 milioane de abonati. Intact: RCSRDS dovedeste rea credinta [online]. HotNews. [Accesat 5 mai 2021]. Disponibil la: https://m.hotnews.ro/stire/12044702

DICKINSON, Tim, 2011. How Roger Ailes Built the Fox News Fear Factory [online]. Rolling Stone. [Accesat 5 mai 2021]. Disponibil la: https://www.rollingstone.com/politics/politics-news/how-roger-ailes-built-thefox-news-fear-factory-244652/

ECONOMY, Elizabeth C., HUANG, Yanzhong, COHEN, Jerome A., SEGAL, Adam şi GEWIRTZ, Julian, 2020. How 2020 Shaped U.S.-China Relations [online]. Council on Foreing Relations. [Accesat 5 mai 2021]. Disponibil la: https://www.cfr.org/article/how-2020-shaped-us-china-relations

FILIPOVIC, Jill, 2020. Fox News Has Manufactured a Boomer War Against Millennials [online]. Gen. [Accesat 5 mai 2021]. Disponibil la: https://gen.medium.com/fox-news-has-manufactured-a-boomer-war-againstmillennials-b8a54ee9fbaf

GILBERT, Sophie, 2017. Get Me Roger Stone Profiles the Man Who Created President Trump [online]. The Atlantic. [Accesat 5 mai 2021]. Disponibil la: https://www.theatlantic.com/entertainment/archive/2017/05/get-me-roger-stonedonald-trump-netflix/526296/

HILL, McGraw, 2015. Presidential Politics, 20th Century Style [online]. Internet Archive. [Accesat 5 mai 2021]. Disponibil la: https://web.archive.org/web/20150818034233/http://www.mhhe.com/socscience/ comm/wilson5/politics_chapter/prez09.html

HOT NEWS, 2014. Traian Basescu: Victor Viorel, iti spun de acum: Or sa primeasca Finantele camioane de facturi pentru oameni care nu au alimentat niciodata/ Daca Ponta nu intelege de unde poate reduce cheltuieli, sint gata sa-i arat in 30 de minute [online]. HotNews. [Accesat 5 mai 2021]. Disponibil la: https://www.hotnews.ro/stiri-esential-16941067-traian-basescu-sustine-lunideclaratie-presa-ora-15-00.htm

IMDB, s.a. Get Me Roger Stone [online]. IMDb Quotes. [Accesat 5 mai 2021]. Disponibil la: https://www.imdb.com/title/tt6714534/quotes/

KIRSCHNER, Noelani, 2021. U.S. sanctions on Venezuela explained [online]. Share America - U.S. Department of State's platform for communicating American foreign policy worldwide. [Accesat 5 mai 2021]. Disponibil la: https://share.america.gov/u-s-sanctions-venezuela-explained/

KURTZ, Howard, 2000. Bush Cousin Made Florida Vote Call For Fox News [online]. The Washington Post. [Accesat 5 mai 2021]. Disponibil la: https://www.washingtonpost.com/archive/lifestyle/2000/11/14/bush-cousinmade-florida-vote-call-for-fox-news/68c8b308-d61e-460f-a4d8-f98371aeab5f/ 
LEPORE, Jill, 2014. Bad News. The reputation of Roger Ailes [online]. The New Yorker. [Accesat 5 mai 2021]. Disponibil la: https://www.newyorker.com/magazine/2014/01/20/bad-news-11

NELSON, L. Jacob, 2019. What is Fox News? Researchers want to know [online]. Columbia Journalism Review. [Accesat 5 mai 2021]. Disponibil la: https://www.cjr.org/tow_center/fox-news-partisan-progaganda-research.php

OHLHEISER, Abby, 2017. The woman behind 'Me Too' knew the power of the phrase when she created it -10 years ago [online]. The Washington Post. [Accesat 21 noiembrie 2021]. Disponibil la: https://www.washingtonpost.com/news/theintersect/wp/2017/10/19/the-woman-behind-me-too-knew-the-power-of-thephrase-when-she-created-it-10-years-ago/

PONIEWOZIK, James, 2020. Donald Trump Was the Real Winner of The Apprentice [online]. The New York Times. [Accesat 5 mai 2021]. Disponibil la: https://www.nytimes.com/2020/09/28/arts/television/trump-taxesapprentice.html

RENATA, Carla, s.a. Why All Politicians Scream Get Me Roger Stone [online]. The Curvy Film Critic. [Accesat 5 mai 2021]. Disponibil la: https://thecurvyfilmcritic.com/why-all-politicians-scream-get-me-roger-stone/

ROTTEN TOMATOES, s.a. The Loudest Voice: Season 1, Critics Consensus [online]. Rotten Tomatoes. [Accesat 5 mai 2021]. Disponibil la: https://www.rottentomatoes.com/tv/the_loudest_voice/s01

STELTER, Brian, 2020. How Fox News has changed in the four years since Roger Ailes was ousted [online]. CNN Business. [Accesat 5 mai 2021]. Disponibil la: https://edition.cnn.com/2020/07/22/media/fox-news-trump-roger-ailes-fouryears-later/index.html

STONE, Roger, 2018. Stone's Rules: How to Win at Politics, Business, and Style [online]. Good Reads. [Accesat 5 mai 2021]. Disponibil la: https://www.goodreads.com/work/quotes/61854942-stone-s-rules-how-to-winat-politics-business-and-style

TAIBBI, Matt, 2015. Donald Trump Claims Authorship of Legendary Reagan Slogan; Has Never Heard of Google [online]. Rolling Stone. [Accesat 5 mai 2021]. Disponibil la: https://www.rollingstone.com/politics/politics-news/donald-trumpclaims-authorship-of-legendary-reagan-slogan-has-never-heard-of-google193834/

TĂPĂLAGĂ, Dan, 2019. Ce se întâmplă la Digi24. Cartelizarea televiziunilor de știri [online]. G4 Media. [Accesat 5 mai 2021]. Disponibil la: https://www.g4media.ro/ce-se-intampla-la-digi24-cartelizarea-televiziunilor-destiri.html

\section{Surse video:}

Get Me Roger Stone, 2017 [film]. Regizori: Dylan BANK, Daniel DIMAURO, Morgan PEHME. SUA, Netflix. 
Ion Indolean

The Loudest Voice, 2019 [mini-serie]. Creatori: Tom MCCARTHY, Alex METCALF. SUA, Showtime.

YOUTUBE, 2010. Interview with Roger Ailes, president of Fox News Channel, canalul Youtube Hoover Institution. [Accesat 5 mai 2021]. Disponibil la: https://www.Youtube.com/watch?v=lHYa9IupxRs\&ab_channel=HooverInstituti on

YOUTUBE, 2012. Noam Chomsky Necessary Illusions, Apr 11 1989, American University | Institute for Policy Studies, canalul Youtube TheEthanwashere, Jul 17, 2012. [Accesat 5 mai 2021]. Disponibil la: https://www.Youtube.com/watch?v=wi1WVEhlMh0\&ab_channel=TheEthanwas $\underline{\text { here }}$

YOUTUBE, 2014. Gabriel Sherman The Loudest Voice in the Room, canalul Youtube Politics and Prose. [Accesat 5 mai 2021]. Disponibil la: https://www.Youtube.com/watch?v=ehtku6qCM90\&ab_channel=PoliticsandPro $\underline{\text { se }}$

YOUTUBE, 2015. Noam Chomsky - Manufacturing Consent, canalul Youtube Chomsky's Philosophy. [Accesat 5 mai 2021]. Disponibil la: https://www.Youtube.com/watch?v=tTBWfkE7BXU\&ab channel=Chomsky\%2 7sPhilosophy

YOUTUBE, 2016. Morning Meeting, 4/17/15: Roger Ailes, Chairman and CEO, FOX News, canalul Youtube The Taft School. [Accesat 5 mai 2021]. Disponibil la: https://www.Youtube.com/watch?v=oW-bT_2u_u8\&ab_channel=TheTaftSchool YOUTUBE, 2016. Roger Ailes Resigns From Fox News, canalul Youtube ABC News. $\begin{array}{llllll}\text { [Accesat } & 5 & \text { mai } & \text { 2021]. }\end{array}$ https://www.Youtube.com/watch?v=0ltsI5ZHpO4\&ab_channel=ABCNews

YOUTUBE, 2017. Noam Chomsky - The 5 Filters of the Mass Media Machine, canalul Youtube Al Jazeera English. [Accesat 5 mai 2021]. Disponibil la: https://www.Youtube.com/watch?v=34LGPIXvU5M\&ab_channel=AlJazeeraEnglish 